\title{
SOCIAL INCLUSION OF CHILDREN \\ DIAGNOSED WITHAUTISM SPECTRUM DISORDER IN INDIA: A LITERATURE REVIEW
}

Malvika Samnani ${ }^{1}$, Sujata Shahi', Manish Samnani ${ }^{3}$, Kanika Nanda ${ }^{4}$, Mansi Srivastava ${ }^{5}$, Pooja Singh ${ }^{6 i}$

${ }^{1}$ Doctorate Scholar, IILM University, Gurgaon, Haryana, India

${ }^{2}$ Professor and Head, Department of Psychology, IILM University, Gurgaon, Haryana, India

${ }^{3}$ Head of Occupational Therapy and Clinical Director, $\mathrm{SOCH}$ Centre for Children with Special Needs,

Gurgaon, Haryana, India

${ }^{4}$ Psychologist, SOCH Centre for Children with Special Needs, Gurgaon, Haryana, India

${ }^{5}$ Research Assistant, SOCH Centre for Children with Special Needs,

Gurgaon, Haryana, India

${ }^{6} \mathrm{Head}$ of Occupational Therapy and Founder, Aarambh Centre for Special Needs, Varanasi, Uttar Pradesh, India

\begin{abstract}
:
Autism Spectrum Disorder is a neurodevelopmental disorder defined by insufficiency in social communication and social interaction skills and restricted and repetitive patterns of behavior. The aim of this research was to analyze empirical studies on inclusion of
\end{abstract}

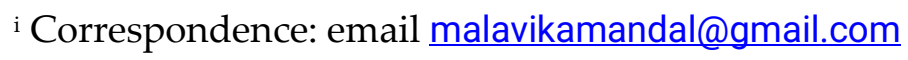


children with Autism in India over the past 20 years and then propose recommendations for future research. A systematic process was used to conduct the review which included identifying the data source, assessing the quality of our studies, and drawing analysis of our findings. The result included different stakeholder's perspectives which were parents and teachers.

Keywords: social inclusion, children diagnosed with autism spectrum disorder, India

\section{Introduction}

Autism spectrum disorders (ASD) is defined by insufficiency in two main areas: lack of social communication skills and social interaction; restricted repetitive patterns of behaviour, interests and activities (American Psychiatric Publishing, 2013). The latest research (CDC 2014) detailed the incidence of ASD increasing to 1 out of 68 children. The lack of social skills is defined by irregular eye contact, attention deficit, eccentric speech patterns, trouble with both starting and sustaining conversations, absence of social critical thinking capacity, lack of compassion, and difficulties in deciphering gestures. (American Psychiatric Publishing, 1994). The children face difficulties in expanding their dialect and comprehending what is heard as well as problems in conveying their reasoning (Halfon N., Kuo A. A., 2013).

With the enactment of the UNCRPD (2006), the importance on educating children with Autism in the general classroom setting has proliferated exceedingly and has become an international movement. Inclusive Education (IE) is given mostly dependent on every one of the kids' entitlements to admittance to gain education close by with their companions paying little heed to their inability (S. Shahzadi, 2006).

For the past three decades, the notion of Inclusive Education (IE) has been approved. There are numerous studies taking place on the outcome of IE in relation to children with learning disabilities. Koegel et al. (2011) proved that IE among special needs children will enhance their social skills and progress further in their academics. According to Allen and Cowdery (2005), Inclusive Education (IE) enhances children's social skills.

\section{Benefits of Social Inclusion}

Frith (1991) proposed that the lack of social and communication skills may affect scholarly conduct which may confine interests, intellectual thinking, trouble with problem solving, paucity in organization skills and having difficulty deciphering information.

According to Lovaas and Smith (2000), children with ASD will benefit more if they are provided with appropriate educational and intervention settings at their young age. The focus on improving social skills in these children can be developed through these educational programmes and curriculums. Inclusive Education provides these benefits 
in the form or peer models and social opportunities. The peer model focuses on the children with ASD being benefited from the planned contact with their normal peers in the classroom.

To exhibit their thoughts, children diagnosed with autism demonstrate atypical / unusual behaviours such as being hostile or violent, having a temper or causing harm to themselves (Kulage K. M. et al., 2014). However, their propensity to convey themselves differs depending on their cognitive and communal growth (Baio J. et al., 2014. Thus, children diagnosed with autism are often perceived first by their social incompetency and a drawback in their communication skills.

During any leisure activity, children diagnosed with autism usually keep aloof or engrossed with themselves instead of being a part of the group or engaging in any play activity (Yaylaci F. et al., 2017). In fact, autistic children should be mingled with normal children in order to enhance educational, social learning and build on their emotional skills (Sturmey P. et al., 2014). Sawitree 2014, found that the learning of these children who are diagnosed with ASD is determined / impacted by the enhancement of their socialisation and communication skills with their friends. Moreover, a significant study done by Howlin \& Goode (1998), asserted that children with ASD are insufficient in their social skill, which is one of the crucial factors needed in their future working environment and their quality of life.

These children with ASD who have been included in the same classroom as normal children will benefit from the planned contact with their non-disabled peers (J. B. Kupersmidt, 2004).

\section{Aim of the Study}

This research aims to review and analyse empirical studies on inclusion of children with Autism in India over the past 20 years and then propose recommendations for future research.

This study offers a compilation of initiatives taken for social inclusion of children diagnosed with autism spectrum disorder in India.

The results of this research will help to draw analysis on the strategies used to promote the social inclusion of these children into educational and other community settings.

\section{Method}

The purpose of this research was to analyse studies on social in lusion in children with autism spectrum disorder in India. A systematic process was used to conduct the review. Three steps were involved to carry on the process which included identifying the data source, a criterion to assess the quality of the studies and drawing analysis of our findings. 
The first step was identifying the data base of studies and the authors have included SCOPUS and PubMed. The search keyword strings used were "social inclusion", "social skills", "autism spectrum disorder" and, "India", which appeared in the title, abstract, or keyword fields. The total number of identified articles from the searches of these databases was 29. Duplicate references were removed. After removing the duplicates, the count was reduced to 24 articles.

We excluded 13 articles by reading the title and abstracts of the study. The inclusion criteria included the following: must be an original study published between (2000-2021); must be published in the English language (non-English studies were excluded). The final number of articles in the analysis was 6 .

\section{Results}

Narayan J. et al., (2005) conducted a study aiming to compile information on current education models like special schools, inclusive schools, home-based instruction, and units established by parent groups. The author's objective was to compile the information on the existing educational situation of children with ASD and analyse the feasibility for replication. In order to achieve the above objective, a questionnaire was sent to all special schools with follow up of one year and the information received was compiled and analysed. The authors found that the choice of model by parents depended on the child's level of functioning and parental aspirations. About $73 \%$ of the parents were eager to send their children to a suitable school, but dissatisfied with the existing facilities.

Another study by Awasthi and Avaramudhan (2019), in which authors used two short and three longitudinal case studies on children with autism to explore the meaning of inclusion and the barriers in the Indian context. A need for understanding inclusion was supported by authors in the context of home environment, education settings and large society. It was found that behaviours such as cooperation, reduction in impulsivity and communication were powerful enablers of inclusion across the different environments. Classrooms also provided a good setting for inclusive experience where fluency was built and appropriate classroom behaviours and specialised training for teachers were targeted.

A study conducted by Shah et al on 560 teachers working in government run schools in Ahmedabad, India was undertaken to determine the concerns of primary school teachers about the inclusion of students with disabilities. A two-part questionnaire was used which gathered personal and professional information of the teachers and the other was a 21 item Likert scale in Gujarati language. It was found that the teachers were least concerned about the lack of social acceptance of the students with disabilities in inclusive education classrooms. Certain parameters were taken into account in order to know why such unacceptability occurred and these were based on gender, background qualification in special education, teaching experience of these teachers and also the number of children with disabilities in a classroom (Shah et al., 2008). 
In contrast, a study by Bhatnagar and Das (2014), conducted two focused group interviews with ten participants each and in addition to this, 20 semi structured interviews were also conducted. The respondents in this study were secondary school teachers working in schools in Delhi, selected from four administrative zones. The study focused on determining the attitude of the regular schoolteachers in Delhi towards the inclusion of students with disabilities. Views regarding facilitators of inclusive education were also explored and flexible qualitative data analysis was utilized. The findings showed that the teachers held a positive attitude towards the inclusion of these students with disabilities and also suggested improved infrastructure, changes in policy and provisions for institutional resources.

A study by Tiwari et al. (2015), focused on the identification and the articulation of teacher's perception and belief on providing educational services to students with disabilities in general classrooms. Semi-structured interviews of 15 teachers of public schools in Delhi were conducted. Constant comparative methods were used and the conclusions were drawn which included that different socio-cultural ideologies have impacted the education of children with disabilities and systematic barriers to education have made the teachers accept the concept of inclusion in theory. Barriers such social factors and lack of training opportunities have hindered the implementation of inclusive education.

Karanth and Chandhok (2013), conducted a study on 296 children through questionnaires which were collected through email, post, telephonic interviews and face to face interviews. The questionnaire covered three major areas which ranged from family's success on completing the recommendations of the early intervention (EI) program, issues faced in schooling and feedback on the EI program. The aim of the study was to follow up on the educational status of children diagnosed with ASD who had been enrolled for the early intervention program. The findings and recommendations concluded that early intervention helps in the enrolment and retention of children diagnosed with autism in mainstream schools.

Priyanka Nimbair et al., (2019) conducted a study which aimed at understanding peer victimization and its relationships to the self-esteem of the children having Mild Intellectual Disability and Borderline Intellectual Functioning issues. A sample of 40 children met the inclusion criteria. The results indicated that peer victimization was more in regular schools than in special schools.

A review study was done by Padmakumari P. et al., (2017) which focused on systematic examinations of different intervention practices which included improvement in social skills in ASD children practiced in India. The study collated 19 different papers published from 2000-2020 and evidence was presented in nine treatment categories. There was higher participation of males with the ages ranging from 1 year to 16 years.

Another study was done with an aim to explore the classroom practices of teachers influencing positive peer interaction between students with and without disabilities in public schools in Tamil Nadu, Chennai, India. The study also helped to determine the teachers attitudes towards students with disabilities and teacher's self-efficacy to foster 
social inclusion. Data was collected was 93 teachers and 923 students in the form of questionnaires, interviews, and classroom observations. The results showed positive attitudes of the teachers towards inclusive education and high self-efficacy to support inclusive schooling (David, R., Kuyini, A. B., 2012).

Few studies also focused on the cross-culture differences to describe social inclusion for children with disabilities. One study done in Ladakh; India explored the meaning of inclusion for children with cognitive disabilities. It was stressed that families should receive as much attention as schools in terms of seeking solutions to maximise social inclusion once the children move back into their families after completing their education. It focused on the need to conceptualize inclusion locally (Koller, D., Pouesard, M. L., Rummens, J. A., 2017).

Table 1

\begin{tabular}{|c|c|c|c|c|c|c|}
\hline $\begin{array}{l}\text { Sr } \\
\text { No. }\end{array}$ & Author & Sample Size & Theme & $\begin{array}{c}\text { Data Collection } \\
\text { Method }\end{array}$ & $\begin{array}{l}\text { Research } \\
\text { Approach }\end{array}$ & $\begin{array}{c}\text { Inclusion } \\
\text { Setting } \\
\end{array}$ \\
\hline 1 & $\begin{array}{l}\text { Narayan J., } \\
\text { Chakravarti S. N., } \\
\text { David J., } \\
\text { Kanniappan M. }\end{array}$ & $\begin{array}{l}\text { Unknown } \\
\text { Sample Size }\end{array}$ & & $\begin{array}{l}\text { Questionnaire was } \\
\text { sent to all special } \\
\text { schools }\end{array}$ & $\begin{array}{l}\text { This study aimed } \\
\text { to compile } \\
\text { information on the } \\
\text { current } \\
\text { educational } \\
\text { models and to find } \\
\text { out the feasibility } \\
\text { for replication. }\end{array}$ & $\begin{array}{l}\text { Special schools, } \\
\text { inclusive schools, } \\
\text { home-based } \\
\text { instruction and } \\
\text { units established by } \\
\text { parent groups. }\end{array}$ \\
\hline 2 & $\begin{array}{l}\text { Aravamudhan S., } \\
\text { Awasthi S. }\end{array}$ & $\begin{array}{l}\text { Participants ( } 3 \\
\text { boys and } 2 \\
\text { girls) aged ( } 4 \\
\text { and } 12 \text { years) } .\end{array}$ & $\begin{array}{l}\text { Barriers and } \\
\text { facilitators }\end{array}$ & Case Study & \begin{tabular}{|l|} 
The authors draw \\
upon their clinical \\
expertise spanning \\
6 and 30 years \\
respectively, use \\
two short-term \\
and three \\
longitudinal case \\
studies of young \\
children with \\
autism to explore \\
the meaning of \\
inclusion, \\
enablers, and \\
barriers in the \\
Indian context.
\end{tabular} & $\begin{array}{l}\text { |l } \\
\text { Home environment, } \\
\text { educational } \\
\text { settings, and larger } \\
\text { society. }\end{array}$ \\
\hline 3 & $\begin{array}{l}\text { Karanth P., } \\
\text { Chandhok T .S. }\end{array}$ & 30 & $\begin{array}{l}\text { Early } \\
\text { intervention }\end{array}$ & $\begin{array}{l}\text { Data was collected } \\
\text { through a } \\
\text { questionnaire. } \\
\text { Contact modes - } \\
\text { email, post, } \\
\text { telephonic } \\
\text { interviews, face-to- } \\
\text { face interviews. }\end{array}$ & \begin{tabular}{|l|} 
A questionnaire \\
(Appendix 1) \\
designed to obtain \\
information \\
relevant to the \\
child's progress \\
after having \\
moved out of the \\
EI program, \\
focusing primarily \\
on issues related \\
to schooling was \\
designed.
\end{tabular} & $\begin{array}{l}\text { Communication } \\
\text { DEALL program at } \\
\text { Bangalore }\end{array}$ \\
\hline
\end{tabular}


SPECTRUM DISORDER IN INDIA: A LITERATURE REVIEW

\begin{tabular}{|c|c|c|c|c|c|c|}
\hline 4 & $\begin{array}{l}\text { Nisha Bhatnagar, } \\
\text { Ajay Das }\end{array}$ & 20 participants & $\begin{array}{l}\text { Teachers' } \\
\text { perspectives }\end{array}$ & $\begin{array}{l}\text { Semi Structured } \\
\text { Interviews } \\
\text { (qualitative) }\end{array}$ & $\begin{array}{l}\text { Two focus group } \\
\text { interviews were } \\
\text { conducted and } \\
\text { each group had } \\
\text { ten participants. In } \\
\text { addition to the } \\
\text { focus group } \\
\text { interviews, } 20 \\
\text { semi-structured } \\
\text { interviews were } \\
\text { conducted with } \\
\text { the teachers } \\
\text { selected from the } \\
\text { four } \\
\text { administrative } \\
\text { zones. }\end{array}$ & $\begin{array}{l} \\
35 \text { secondary } \\
\text { schools in four } \\
\text { administrative } \\
\text { zones of Delhi: East, } \\
\text { West, North and } \\
\text { South. }\end{array}$ \\
\hline 5 & $\begin{array}{l}\text { Rina Shah, Ajay } \\
\text { Das, Ishwar Desai } \\
\text { and Ashwini } \\
\text { Tiwari }\end{array}$ & 560 teachers & $\begin{array}{l}\text { Teachers' } \\
\text { perspectives }\end{array}$ & $\begin{array}{l}\text { A two-part } \\
\text { questionnaire was } \\
\text { used in this study. } \\
\text { (survey) }\end{array}$ & \begin{tabular}{|l|} 
Part 1 gathered \\
information \\
relating to \\
personal \\
and professional \\
characteristics of \\
the teachers. \\
Part 2 was a 21- \\
item Likert scale \\
titled \\
Concerns about \\
Inclusive \\
Education - \\
Gujarati.
\end{tabular} & $\begin{array}{l}\text { Working in } \\
\text { government- run } \\
\text { schools }\end{array}$ \\
\hline 6 & $\begin{array}{l}\text { Ashwini Tiwari } \\
\text { A.,, Ajay Das, } \\
\text { Manisha Sharma }\end{array}$ & 15 & $\begin{array}{l}\text { Teachers' } \\
\text { perspectives }\end{array}$ & \begin{tabular}{|l|} 
Hermeneutic \\
phenomenology, \\
The data were \\
analyzed using a \\
constant \\
comparative \\
method. (qualitative) \\
\end{tabular} & $\begin{array}{l}15 \text { semistructured } \\
\text { interviews of } \\
\text { public school } \\
\text { teachers in Delhi } \\
\text { were conducted. } \\
\text { Each interview, } \\
\text { lasting from } 30 \\
\text { to } 45 \text { min, was } \\
\text { recorded and } \\
\text { transcribed. }\end{array}$ & $\begin{array}{l}\text { Public school } \\
\text { teachers in Delhi }\end{array}$ \\
\hline 7 & $\begin{array}{l}\text { Nambiar P., } \\
\text { Jangam K., } \\
\text { Roopesh B. N., } \\
\text { Bhaskar A. }\end{array}$ & 40 & $\begin{array}{l}\text { Peer } \\
\text { victimization } \\
\text { and self esteem }\end{array}$ & Questionnaire & $\begin{array}{l}\text { The study utilized } \\
\text { a cross-sectional } \\
\text { research design } \\
\text { with a sample of } \\
40 \text { children who } \\
\text { met the inclusion } \\
\text { criteria. }\end{array}$ & $\begin{array}{l}\text { The participants } \\
\text { were recruited from } \\
\text { the outpatient (OP) } \\
\text { and inpatient (IP) } \\
\text { services of Child } \\
\text { and Adolescent } \\
\text { Psychiatry } \\
\text { Department of the } \\
\text { research institution } \\
\text { as well as from SS } \\
\text { facilities. }\end{array}$ \\
\hline 8 & $\begin{array}{l}\text { Alexander, A. E., } \\
\text { Padmakumari, P., } \\
\text { Padavan, I. D. }\end{array}$ & 19 Studies & $\begin{array}{l}\text { Different } \\
\text { intervention } \\
\text { practices that } \\
\text { include } \\
\text { improvement of }\end{array}$ & $\begin{array}{l}\text { Studies published } \\
\text { from } 2000 \text { to } 2020 \\
\text { were selected for the } \\
\text { study. These studies } \\
\text { were drawn from }\end{array}$ & Review Study & $\begin{array}{l}\text { Children with ASD } \\
\text { in India }\end{array}$ \\
\hline
\end{tabular}




\begin{tabular}{|c|c|c|c|c|c|c|}
\hline & & & $\begin{array}{l}\text { social skills in } \\
\text { ASD that is } \\
\text { practiced in } \\
\text { India }\end{array}$ & $\begin{array}{l}\text { databases Ebsco, } \\
\text { Proquest, PubMed, } \\
\text { MEDLINE, science } \\
\text { direct and Google } \\
\text { Scholar. }\end{array}$ & & \\
\hline 9 & $\begin{array}{l}\text { David, R., } \\
\text { Kuyini, A.B. }\end{array}$ & \begin{tabular}{|l} 
Data were \\
collected from \\
a sample of 93 \\
primary \\
school \\
teachers and a \\
total of 923 \\
students \\
\end{tabular} & \begin{tabular}{|l|} 
Teacher's \\
perspectives
\end{tabular} & $\begin{array}{l}\text { Questionnaires, } \\
\text { interviews and } \\
\text { classroom } \\
\text { observations }\end{array}$ & $\begin{array}{l}\text { Survey } \\
\text { questionnaires } \\
\text { and participant } \\
\text { observation along } \\
\text { with interviews }\end{array}$ & $\begin{array}{l}\text { Punchayat Union } \\
\text { Schools (public } \\
\text { schools). }\end{array}$ \\
\hline 10 & $\begin{array}{l}\text { Koller, D., } \\
\text { Pouesard, M.L., } \\
\text { Rummens, J.A. }\end{array}$ & Unknown & $\begin{array}{l}\text { Cross Culture } \\
\text { Variables }\end{array}$ & $\begin{array}{l}\text { The search was } \\
\text { conducted on a } \\
\text { biweekly basis from } \\
\text { December } 2014 \text { to } \\
\text { March 2015, using } \\
\text { six databases }\end{array}$ & $\begin{array}{l}\text { Peer-reviewed } \\
\text { original studies } \\
\text { published } \\
\text { between January } \\
2004 \text { and March } \\
2015 .\end{array}$ & Ladakh, India \\
\hline
\end{tabular}

\section{Discussion}

The above research gathered studies done on inclusion in the past 20 years. Most of the studies took a descriptive method approach using surveys whereas the others used a qualitative method.

In India there is a huge paucity of research for inclusion of children and rarity of information for inclusion of children with autism in mainstream schooling.

Three of the studies have focused on the perception of teachers on inclusion of children with disabilities. Some studies reflected a positive attitude while some still depicted a question on the whole idea of inclusion. Thus, these studies have found mixed results and there are concerns about teachers' attitudes and knowledge about inclusion. It is noteworthy that none of the studies have focused on the Autism population specifically but have included autism as part of other disabilities.

There is one study that has focused on barriers and facilitators of inclusion and has focused on children with autism. However, the authors have included only 5 children who cannot be a true representation of the autism population in a vast and populous country like India.

Only one study has done a follow up of children who received early intervention and found that children who receive therapy do retain in the schools and are able to adjust better.

\section{Conclusion}

The prevalence of Autism in India is $0.9 \%$ in the age group of children (0-15 years). Research shows that most students perform better when exposed towards the general education curriculum. Children do better academically when in inclusive settings and inclusion provides opportunities to develop a better understanding of relationships. 
However, the review of literature states that there is a dearth of research on what has been done on implementation of inclusion of children with autism in India. Teachers' perception has been sought but no studies focused on perception of peers, and caregivers towards the concept of inclusion. One of the studies has studied various models that are availed by parents of children with Autism including mainstream schools and has categorically revealed that $73 \%$ parents were unsatisfied with the existing facilities.

It is needed that more research should be done and factors contributing to the understanding and implementation of inclusive education should be studied and more information should be added to the challenges and enablers.

It is also important to examine the effects of inclusion exclusively focusing on the autism population rather than as part of various disabilities.

\section{Conflict of Interest Statement}

The authors declare that there is no potential conflicts of interest with respect to the research, authorship and / or publication of this article.

\section{About the Authors}

Malvika Samnani, Doctorate Scholar, IILM University, Gurgaon, India is an Occupational Therapist and runs a centre for children with special needs "SOCH" in Gurgaon. The author has been working for the inclusion and social skills of children with Autism for 15 years. She has been trained through various post professional programs and certifications including Program for the Education and Enrichment of Relational Skills. (PEERS).

Sujata Shahi, Professor and Head, Department of Psychology at IILM University, Gurgaon, Haryana, India has a doctorate in psychology, and a post graduate diploma in Journalism. She is Lead faculty. She is principal of the college of psychology and guide to the doctorate scholars.

Manish Samnani, Head of Occupational Therapy and Clinical Director SOCH centre for special needs, Gurgaon, Haryana, India is pursuing doctorate in Occupational Therapy from Maharaj Vinayak Global University, Jaipur, India.

Kanika Nanda is a psychologist at $\mathrm{SOCH}$, centre for children with special needs. The coauthor is pursuing post-graduation in Clinical Psychology at Amity University, Gurugram, Haryana, India. She is a graduate in applied psychology and has a PostGraduation Diploma in Counselling Psychology.

Mansi Srivastava, Research Assistant at SOCH centre for children with special needs. The co-author is a post-graduate in psychology.

Pooja Singh, Head of Occupational Therapy and Founder of Aarambh Centre for Special Needs, Varanasi (Uttar Pradesh), India. The co-author is a postgraduate in Occupational Therapy. 


\section{References}

Alam D. S., Robinson H., Kanungo A., Hossain M. D., Hassan M. (2013). Health Systems preparedness for responding to the growing burden of non-communicable disease-a case study of Bangladesh (Working Paper No 25). The Nossal Institute for Global Health, The University of Melbourne, AusAID Knowledge Hub for Health. 2013.

Aravamudhan, Sridhar Awasthi, Smita (2019). Inclusion in Home, Social, and Educational Settings for Children with Autism in India - Enablers and Challenges: Insights from Educators across World DO - 10.1007/978-981-13-5962-0_25

Abbagani, K. L. (2006). A study of children with autism and effectiveness of psychosocial interventions with them. The thesis submitted to the Osmania University for the award of Degree of Doctor of Philosophy in social Work June 2006.

American Psychiatric Association (2013). Diagnostic and statistical manual of mental disorders. 5th ed. Arlington: American Psychiatric Publishing

American Psychiatric Association (1994). Diagnostic and statistical manual of mental disorders. 4th ed. Washington: American Psychiatric Publishing

Ashwini Tiwari, Ajay Das, Manisha Sharma (2015). Inclusive education a "rhetoric" or "reality"? Teachers' perspectives and beliefs, Teaching and Teacher Education, Volume 52, 2015, Pages 128-136, ISSN 0742-051X, https://doi.org/10.1016/j.tate.2015.09.002

Attitudes of Secondary School Teachers towards Inclusive Education in New Delhi, India January 2013 Journal of Research in Special Educational Needs 14(4) DOI:10.1111/1471-3802.12016

Bhatnagar Das Ajay (2014). Attitudes of Secondary Regular School Teachers Toward Inclusive Education in New Delhi, India: A Qualitative Study 24 DO10.5206/eei.v24i2.7712 Exceptionality Education International

Baio J., Wiggins L., Christensen D. L., et al. (2014). Prevalence of autism spectrum disorder among children aged 8 years - autism and developmental disabilities monitoring network, 11 sites, United States, 2014. MMWR Surveill Summ 2018; 67:1-23. 10.15585/mmwr. ss6706a1

F. M. Gresham (1998). Social Skill Training with Children: Social Learning and Applied Behavioral Analytic Approaches. In T. S. Watson \& F. M. Gresham (Eds.), Handbook of Child Behavior Therapy (pp.475-497), New York: Plenum Press, 1998. [14] J. B. Kupersmidt, M. E. DeRosier

Guralnick M. J. (1998). The effectiveness of early intervention for vulnerable children: A developmental perspective. AJMR; 102:319-45.

Ghosh, M., Shah, A. H., Dhir, K., \& Merchant, K. F. (2008). Behavior in children with Down syndrome. Indian Journal of Pediatrics, 75(7), 685-689. https://doi.org/10.1007/s12098-008-0129-z

Halfon N., Kuo A. A. (2013). What DSM-5 could mean to children with autism and their families. JAMA Pediatr ; 167:608-13. 10.1001/jamapediatrics.2013.2188 
Hume K, Bellini S, Pratt C. (2006). The usage and perceived outcomes of early intervention and early childhood programs for young children with autism spectrum disorder. Topics Early Child Spec Educ.; 25:195-207.

How Peer Problems Led to Negative Outcomes: An Integrative Mediational Model. In J. B. Kupersmidt \& K. A. Dodge (Eds.), Children's Peer Relations: From Development to Intervention (pp.119-138), Washington: American Psychological Association.

Hartley-McAndrew M, Mertz J, Hoffman M, et al. (2004). Rates of autism spectrum disorder diagnosis under the DSM-5 criteria compared to DSM-IV-TR criteria in a hospital-based clinic. Pediatr Neurol 2016; 57:34-8. 10.1016/j.pediatrneurol.2016.01.012

J. B. Kupersmidt, M. E. DeRosier (2004). How Peer Problems Led to Negative Outcomes: An Integrative Mediational Model. In J. B. Kupersmidt \& K.A. Dodge (Eds.), Children's Peer Relations: From Development to Intervention (pp.119-138), Washington: American Psychological Association

Kumar, S., Alexander, M., \& Gnanamuthu, C. (2004). Recent experience with Rett syndrome at a tertiary care center. Neurology India, 52(4), 494.

Katsiyannis, E. Dragsow, M. Herbst. (2006). Developing Legally Correct and Educationally Appropriate Programs for Students with Autism Spectrum Disorders, Focus on Autism \& other Developmental Disabilities, Vol.18, No.3, 182192

Karanth P, Srikanth N, Roche A, et al. (2008). The Com DEALL program \& Com DEALL intervention manuals for toddlers \& pre-schoolers. Bangalore: The Com DEALL Trust, 2008; 2010. p. 1-10.

Karanth P, Shaista S, Srikanth N. (2010). Efficacy of communication DEALL-an indigenous early intervention program for children with autism spectrum disorders. Indian J Pediatr. 2010; 77:957-62.

Kulage K. M., Smaldone A. M., Cohn E. G. (2014). How will DSM-5 affect autism diagnosis? A systematic literature review and meta-analysis. J Autism Dev Disord; 44:1918-32. 10.1007/s10803-014-2065-2

Katsiyannis, E. Dragsow, M. Herbst (2014). Developing Legally Correct and Educationally Appropriate Programs for Students with Autism Spectrum Disorders, Focus on Autism \& other Developmental Disabilities, Vol.18, No.3, 182192.

Lal, R., \& Ganesan, K. (2011). Children with autism spectrum disorders: Social Stories and self-management of behaviour. British Journal of Educational Research, 1(1), $36-48$.

L. Wing (1988).The Continuum of Autistic Characteristics, in Schopler, E. and Mesibow, G (eds) Diagnosis and assessment in autism, Plenum Press, New York, 1988.

Malhi, P., Venkatesh, L., Bharti, B., \& Singhi, P. (2017). The Indian Journal of Paediatrics, 84(4), 283-288. https://doi.org/10.1007/s12098-016-2285-x 
National Research Council (2001). Educating children with autism. Committee on educational interventions for children with autism. In: Lord C, McGee JP, eds. Division of behavioral and social sciences and education. Washington: National Academy Press

Narayan, J., Chakravarti, S. N., David, J., \& Kanniappan, M. (2005). Analysis of educational support systems for children with mental retardation and autism spectrum disorders. International Journal of Rehabilitation Research, 28(4), 365368. https://doi.org/10.1097/00004356- 200512000-00011

O. I. Lovaas (2020) Behavioral treatment and normal educational and intellectual functioning in young autistic children, Journal of Consulting and Clinical Psychology, Vol.55, 3-9.

P. Howlin, S. Goode (1998). Outcome in Adult Life for People with Autism, Asperger Syndrome. In F. R. Volkmar (Eds.), Autism and Pervasive Developmental Disorders (pp.209-241), New York: Cambridge University Press, 1998

Rogers S. J. (1998). Empirically supported comprehensive treatments for young children with autism. J Clin Child Psychol; 27:168-79.

Srivastava, Seema, \& Mukhopadhyay, Anjana (2011). Optimism-pessimism and emotional competence measures of parents of children with symptoms of autism. Indian Journal of Community Psychology, 7(1), 130-138.

Szatmari P. (1998). Heterogeneity and the genetics of autism. J Psychiatry Neurosci (1998). 24:159-65.

Sturmey P., Dalfern S. (2014). The effects of DSM5 autism diagnostic criteria on number of individuals diagnosed with autism spectrum disorders: a systematic review. Rev J Autism Dev Disord; 1:249-52. 10.1007/s40489-014-0016-7

S. Shahzadi (2000). Inclusive Education: Perspective of Service, International Special Education Congress 2000, University of Manchester, 234-239, 2000.

S. N. Elliott, D. N. Mckinnie (2017). Relationships and Differences among Social Skills, Problem Behavior, and Academic competence for mainstreamed learningdisabled and non-handicapped students, Canadian Journal of School Psychology, Vol.10, 1-14.

T. Smith, A. D. Groen, J. W. Wynn (2018). Randomized trial of intensive early intervention for children with pervasive developmental disorder, American Journal on Mental Retardation, Vol.105, 269-285.

Teachers' concerns about inclusive education in Ahmedabad, India January 2014 Journal of Research in Special Educational Needs 16(1) DOI:10.1111/1471-3802.12054

U. Frith (1991). Autism and Asperger Syndrome, Cambridge University Press, New York UNESCO (1994). Access and Quality, World Conference on Special Needs Education, Salamanca, 1994.

UNESCO (1999). Salamanca-five years on: A review of UNESCO activities in the light of the Salamanca Statement and Framework for Action on Special Needs Education, Paris, 1999. 
WHO (1992). The ICD-10 Classification of Mental and Behavioral Disorders: Clinical Descriptions and Diagnostic Guidelines, Geneva, 1992.

Yaylaci F, Miral S. (2017). A comparison of DSM-IV-TR and DSM-5 diagnostic classifications in the clinical diagnosis of autistic spectrum disorder. J Autism Dev Disord 2017; 47:101-9. 10.1007/s10803-016-2937-8.

Creative Commons licensing terms

Authors will retain the copyright of their published articles agreeing that a Creative Commons Attribution 4.0 International License (CC BY 4.0) terms will be applied to their work. Under the terms of this license, no permission is required from the author(s) or publisher for members of the community to copy, distribute, transmit or adapt the article content, providing a proper, prominent and unambiguous attribution to the authors in a manner that makes clear that the materials are being reused under permission of a Creative Commons License. Views, opinions and conclusions expressed in this research article are views, opinions and conclusions of the author(s). Open Access Publishing Group and European Journal of Special Education Research shall not be responsible or answerable for any loss, damage or liability caused in relation to/arising out of conflict of interests, copyright violations and inappropriate or inaccurate use of any kind content related or integrated on the research work. All the published works are meeting the Open Access Publishing requirements and can be freely accessed, shared, modified, distributed and used in educational, commercial and non-commercial purposes under a Creative Commons Attribution 4.0 International License (CC BY 4.0). 